\title{
Role of Cystatin-C as Serum Biomarkers in Predicting Glomerular Function- Associated with Copper-Induced Acute Kidney Injury
}

\author{
Fiska Maya Wardhani, Linda Chiuman, Chrismis Novalinda Ginting, Sahna Ferdinand Ginting \\ Faculty of Medicine Universitas Prima Indonesia, Medan, Indonesia
}

\begin{abstract}
Cystatin $\mathrm{C}$ is a $13 \mathrm{kD}$ molecular-weight protein synthesized by all nucleated cells which functions as a cysteine protease inhibitor. Cystatin $\mathrm{C}$ is detectable when kidney function decreases due to the excessive accumulation of nephrotoxic substances such as copper. Previous studies have proven that, white turmeric rhizome can act as a nephroprotector agent at a dose of $500 \mathrm{mg} / \mathrm{BW}$. The purpose of this study is compare Cystatin-C marker and serum creatinine as biomarkers in the examination of acute kidney injuries induced by nephrotoxic substance. This was a post-test only controlled experimental study on wistar strain male rats that were divided randomly using simple random sampling approach into three groups; normal control group, treatment control group (Curcumin for 2 weeks followed by $\mathrm{CuSO} 4$ for 3 days at each weekend), and CuSO4 pentahydrate control group. This research is conducted at Faculty of Pharmacy and Faculty of Medicine at the University of North Sumatera in May to August 2019. The analysis results is normally distributed and has significant differences in levels of Cystatin-C, creatinine and protein serum due to differences in the treatment of each group where $\mathrm{p}<0.05$. Serum Cystatin-C as a biomarker in this study shows more sensitive in detecting acute kidney damage compared to serum creatinine.
\end{abstract}

Key words: Copper, cystatin-C, nephroprotector, nephrotoxic, white turmeric

\section{Peran Cystatin-C sebagai Biomarker Serum dalam Memprediksi Fungsi Glomerulus-Terkait dengan Cedera Ginjal Akut yang Dipicu Tembaga}

\begin{abstract}
Abstrak
Cystatin C adalah protein dengan berat molekul $13 \mathrm{kD}$ disintesis oleh setiap sel yang memiliki inti berfungsi sebagai inhibitor protease sistein. Cystatin C terdeteksi ketika fungsi ginjal menurun oleh zat nefrotoksik seperti tembaga. Tembaga merupakan salah satu logam yang dapat menjadi zat nefrotoksik bila terakumulasi berlebihan. Ekstrak rimpang kunyit putih memiliki manfaat sebagai nefroprotektor dengan dosis $\mathrm{mg} / \mathrm{kgBB}$. Penelitian ini dilakukan untuk mengetahui perbandingan Cystatin-C dan kreatinin serum sebagai biomarker dalam pemeriksaan kerusakan ginjal akut akibat zat nefrotoksik. Penelitian eksperimental ini menggunakan the post test only control group design dengan teknik simple random sampling. Penelitian ini dilakukan di Fakultas Farmasi dan Fakultas Kedokteran Universitas Sumatera Utara pada bulan Mei hingga Agustus 2019. Tikus jantan dengan galur wistar dibagi tiga kelompok; kontrol normal, kontrol kunyit putih (500 mg/kgBB) sebagai pre-treatment (curcumin selama 2 minggu diikuti $\mathrm{CuSO}_{4}$ selama 3 hari di setiap akhir pekan), dan kontrol $\mathrm{CuSO}_{4}$ pentahidrat. Hasil analisis data terdistribusi normal dan terdapat perbedaan yang signifikan kadar Cystatin-C, kreatinin dan protein serum pada setiap kelompok dimana nilai $\mathrm{p}<0.05$. Cystatin-C serum sebagai biomarker lebih sensitif dalam mendeteksi kerusakan ginjal akut dibandingkan kreatinin serum.
\end{abstract}

Kata kunci: Cystatin-C, kunyit putih, nefroprotektor, nefrotoksik, tembaga

Corresponding Author: Fiska Maya Wardhani, Faculty of Medicine, Universitas Prima Indonesia, Medan, Indonesia, Email: drfiska. mw@gmail.com 


\section{Introduction}

Copper is a macromineral metal group needed to build a body system fluid balance, protein structure, controlling the production of hormones and components of vitamin B12. ${ }^{1}$ However, copper became toxic substance if the amount accumulates. ${ }^{2}$ Nephrotoxic substances will reduced glomerular filtration rate, disruption of the proximal tubule reabsorption, shifts in blood urea nitrogen and serum creatinine, and urine output. Curcumin in curcuma zedoaria has a nephroprotective effect. ${ }^{3}$ Curcumin has an antioxidant effect on toxic substances that can damage kidney cells. Generally, biomarkers for kidney injury caused by nephrotoxic substances are serum creatinine, urea, protein, urinalysis. ${ }^{4}$

Cystatin- $\mathrm{C}$ is one of many biomarkers that sensitively detect an acute renal function disorders. ${ }^{5}$ Cystatin $C$ is a superfamily member of cystatin cysteine protease inhibitors with a molecular weight of $13.3 \mathrm{kDa}$. Almost all cells that have a nucleus synthesize Cystatin C in a constant amount. ${ }^{6}$ Previous studies have shown glomerular and proximal tubule damage by administering nephrotoxic substances CuSO4, followed changes in the parameters of serum ureum and creatinine but also shows a nephroprotective effects of glomerular and proximal tubule from the administration of white turmeric. ${ }^{7}$ The purpose of this research is to compare serum creatinine and serum Cystatin-C biomarkers, and renal histopathology. Groups of wistar rats is divided into three groups; controlled group, group with nephrotoxic (CuSO4 pentahydrate) and group with white turmeric extract as nephroprotector.

\section{Methods}

This study is an experimental with the post test only control group design. The samples are collected by simple random sampling technique. This study is conducted at the Pharmacology and Toxicology Laboratory of the Faculty of Pharmacy, Department of Histology of the Faculty of Medicine, and the Integrated Laboratory of the Faculty of Medicine, Universitas Sumatera Utara Medan from July 2019 until September 2019. This study has received ethical worth from the Health Research Ethics Commission (KEPK) of the University of Prima Indonesia with the number: 001/KEKPK/UNPRI/III/2019.

Test animals are 27 white rats (Rattus noverticus) male Wistar strain, with 6-8 weeks of age and 180-200 grams body weight. The sample size of this study is determined based on Federer formula experimental tests, i.e. ( $t$ 1) $(n-1) \geq 15$. Rats is divided into 3 groups with a total sample of 9 animals so that a total sample of 27 rats. White turmeric rhizome plant in form of dried turmeric white dried simplicia powder is derived from UPT Materia Medica Batu, East Java and the nephrotoxic substance $\mathrm{CuSO} 4$ pentahydrate ordered from PT. Artha Jaya Sanatyasa Chemindo, Jakarta.

The extraction was taken at Faculty of Pharmacy, University of North Sumatera. White turmeric extract is made by maceration using ethanol 96\%, distilled 10 times the weight of white turmeric powder. About 1000 gram white turmeric powder put into container and $96 \%$ ethanol was added 75 parts (7.5 liters). White turmeric powder is soaked for 5 days while stirring frequently and protected from light then filtered or cleaned. The filtered white turmeric pulp is soaked again with the rest of $96 \%$ ethanol (2.5 liters) for 2 days then filtered. The filtrate is combined and concentrated with a rotary evaporator until an almost thick extract is obtained. The thick extract was obatained by evaporating in a water bath.

Male Wistar rats kept in the Pharmacology and Toxicology Laboratory of the USU Faculty of Pharmacy. Samples of 27 male rats were grouped randomly into 3 groups, each group consist 9 rats. Group 1,1F, and 1F2 are normal group given only standard food and drink and sacrificed consecutively at week 1 , week 2 and week 3 . Group 2, 2F, and 2F2 the pre-treatment group, is given with white turmeric extract $45 \mathrm{mg} / 200 \mathrm{gr}$ for 14 days followed by CuSO 4 pentahydrate once a day for 3 days on each weekend and would be sacrificed consecutively at 1 st, 2 nd and 3 rd week Group 3, 3F, and 3F2 the positive control group are given solution $\mathrm{CuSO} 4$ pentahydrate $0.36 \mathrm{mg}$ / 200 gr administered orally using intragastric oral tubes once a day for 3 days on each weekend and sacrificed consecutively at $1^{\text {st }}, 2^{\text {nd }}, 3^{\text {rd }}$ week.

The dosage of test material given in this study was determined based on the results of previous studies, where the best dose of white turmeric extract as a nephroprotector was $500 \mathrm{mg} / \mathrm{kg}$ body weight with the conversion factor calculation method. The dosage of $\mathrm{CuSO} 4$ pentahydrate nephrotoxic test material is 0.36 $\mathrm{mg} / 200$ gr body rat.

On day 7,14 , and 21 each group of rats was sacrificed (euthanised) using Ketamin 0,5 mg/ $\mathrm{kg}$ BW. A total of 2-3 milliliters of blood is taken intracardiacly, after 10 minutes the blood which 
FM Wardhani, et al.: Role of Cystatin-C as Serum Biomarkers in Predicting Glomerular Function-Associated with Copper-Induced Acute Kidney Injury

Table 1 Mean Serum Creatinine

\begin{tabular}{lccc}
\hline \multicolumn{1}{c}{ Treatment Groups } & \multicolumn{3}{c}{ Treatments } \\
\cline { 2 - 4 } & $\begin{array}{c}\text { 7 Days } \\
\text { Mean } \pm \text { SD }\end{array}$ & $\begin{array}{c}\text { 14 Days } \\
\text { Mean } \pm \text { SD }\end{array}$ & $\begin{array}{c}\text { 21 Days } \\
\text { Mean } \pm \text { SD }\end{array}$ \\
\hline Normal control $\left.^{*}\right)$ & $0.65 \pm 0.14$ & $0.71 \pm 0.10$ & $0.88 \pm 0.21$ \\
$\begin{array}{l}\text { Pre-Treatment White Tumeric-CuSO } \\
\text { Pentahidrat }\end{array}$ & $0.68 \pm 0.11$ & $0.79 \pm 0.11$ & $0.81 \pm 0.10$ \\
CuSO4 control groups $^{(* *)}$ & $0.85 \pm 0.20$ & $1.11 \pm 0.35$ & $1.24 \pm 0.45$ \\
\hline Adjective: & & & \\
\hline
\end{tabular}

Adjective: Meanserum creatinine \pm standard deviation(SD) $n=5 .\left(^{*}\right)$ Normal control groups; $(* *)$ the pretreatment group; $\left({ }^{* * *}\right)$ groups induced with CuSO 4 pentahydrate; Creatinine normal value $0.2-0.8 \mathrm{mg} / \mathrm{dl}^{\left({ }^{(8)}\right.}$

has been freezed will be centrifuged at 3000 rpm for 10 minute. The centrifuged blood will be formed into serum and collected about $2 \mathrm{ml}$ in sterile micro tubes and analyses biochemically and assay (ELISA) procedure.

Surgery is performed to remove kidney organs for histopathological preparations using Hematoxylin Eosin (HE) staining with five different views with magnification of $100 x$ and 400x. In each field of view seen damage (necrosis) of kidney cells marked in the form of glomerular wasting, cloudy swelling, and renal tubular occlusion.

Data are taken from the entire control group and treatment group were tested for normality and continued with the two way ANOVA parametric test, if the data were not normally distributed then it was carried out with the Friedman test. To find out the average difference in observations in each treatment group using the Post Hoc Tuckey multiple distance test with the help of SPSS (Statistical Package for the Social Sciences) software 25.00 for Windows.

\section{Results}

Serum examinations is carried out in Dore's
Animal Clinic Laboratory using the Vet Semiauto Chemistry Analyzer (Rayto RT-1904CV). Laboratory serum creatinine test results (Table 1) Mean Group 1 (normal control), Group 2 given pre-treatment of white turmeric extract $45 \mathrm{mg} / 200 \mathrm{gr}$ for 14 days followed by $\mathrm{CuSO} 4$ pentahydrate for 3 days every weekend, and Group 3 administered nephrotoxic solution of CuSO 4 pentahydrate $0.36 \mathrm{mg} / 200 \mathrm{gr}$ showed significant difference (Sig 0.013). However, the duration of treatment does not have a meaningful divergence among the handling groups (Sig 0.859). Gradually serum creatinine of Group 3 have changes in 14 and 21 days treatment (1.11 $\pm 0.35 ; 1.24 \pm 0.45)$.

Laboratory test results for serum Cystatin-C of Group 1 (normal control group), Group 2 and Group 3 shows significant differences (Sig 0.00). However, the duration of treatment do not show any significant difference among the handling groups (Sig 0.504) where serum levels of Cystatin-C in Group 1, Group 2 and Group 3 on day 7,14 and 21 has a constant value, however group 3 shows that Cystatin-C levels is decrease relatively compared to other groups (Table 2).

All data are normally distributed ( $p>0.05)$, and two-way ANOVA parametric tests was performed with the results meaningful difference in each

Table 2 Mean Serum Cystatin-C

\begin{tabular}{|c|c|c|c|}
\hline \multirow{3}{*}{ TreatmentGroups } & \multicolumn{3}{|c|}{ Treatments } \\
\hline & 7 Days & 14 Days & 21 Days \\
\hline & Mean \pm SD & Mean \pm SD & Mean \pm SD \\
\hline $\operatorname{Normal~control}^{(*)}$ & $0.33 \pm 0.06$ & $0.33 \pm 0.12$ & $0.37 \pm 0.05$ \\
\hline $\begin{array}{l}\text { Pre-TreatmentWhite Tumeric-CuSO4 } \\
\left.\text { Pentahidrat }^{(* *}\right)\end{array}$ & $0.25 \pm 0.15$ & $0.25 \pm 0.05$ & $0.27 \pm 0.04$ \\
\hline CuSO 4 control groups $\left({ }^{* * *}\right)$ & $0.22 \pm 0.01$ & $0.22 \pm 0.01$ & $0.21 \pm 0.01$ \\
\hline
\end{tabular}

Adjective: Mean serum creatinine \pm standard deviation(SD) $n=5$. $\left(^{*}\right)$ Normal control groups; $*^{* *}$ )the pretreatment group; ${ }^{* * *}$ ) groups induced with CuSO4 pentahydrate; The maximum Cystatin-C concentration value is 3.182 and a minimum of 0.208 
FM Wardhani, et al.: Role of Cystatin-C as Serum Biomarkers in Predicting Glomerular Function-Associated with Copper-Induced Acute Kidney Injury

Table 3 Mean Serum Protein

\begin{tabular}{lccc}
\hline \multicolumn{1}{c}{ Treatment Groups } & \multicolumn{3}{c}{ Treatments } \\
\cline { 2 - 4 } & $\begin{array}{c}\text { 7 Days } \\
\text { Mean } \pm \text { SD }\end{array}$ & 7 Days & 7 Days \\
& $6.37 \pm 0.66$ & $7.15 \pm 1.40$ & $6.67 \pm 0.65$ \\
\hline Normal Control $^{(*)}$ & $7.35 \pm 1.14$ & $8.30 \pm 1.05$ & $8.80 \pm 1.18$ \\
Pre-Treatment White Tumeric-CuSO & $5.45 \pm 0.65$ & $5.14 \pm 0.56$ & $4.85 \pm 0.75$ \\
Pentahidrat $^{(* *)}$ & CuSO $_{4}$ Control Groups $^{(* * *)}$ & & Mean \pm SD \\
\hline
\end{tabular}

Adjective: Meanserum creatinine \pm standard deviation(SD) $n=5 .\left(^{*}\right)$ Normal control groups; $(* *)$ the pretreatment group; $\left(^{* * *}\right)$ groups induced with CuSO4 pentahydrate;Normal value of serum protein is 5.6-7.6 gr/dL. ${ }^{(8)}$

group. Serum protein levels in group 3 (CuSO4 pentahydrate treatment) changes respectively (Table 3). While the serum protein levels in Group 2 treated with white turmeric extract is increase $(6.37 \pm 0.66 ; 7.15 \pm 1.40 ; 6.67 \pm 0.65)$.

Pre-treatment of white turmeric extract do not show any significant histopathological changes on day 7, 14 and 21 (Table 4). However, the histopathological results of group 3 shows significant changes $(3.25 \pm 0.50 ; \quad 9.00 \pm 0.00$; $9.00 \pm 0.00$ ) gradually decreasing along with the duration of treatment. Glomerulus shows Bowman's lumen opened out, occlusion of proximal tubules, and swelling degeneration (prolonged swelling) (Figure 1).

The data are normally distributed $(\mathrm{p}>0.05)$ proceed to the two way ANOVA parametric statistical test. Based on the two way test results ANOVA, $p$ value of serum creatinine, protein and Cystatin-C and histopathological score of each treatment was $0,000(p<0.05)$. The test continued with post Hoc Tukey to see the distribution of relationships between treatments, where Group 3 had the most significant differences with groups 1 and 2 .

\section{Discussion}

This research goal is to compare the renal biomarkers of creatinine, Cystatin- $\mathrm{C}$, protein serum and renal histopathology in assessing kidney function and early damage in the group treated with $\mathrm{CuSo} 4$ pentahydrate and white turmeric extract pretreatment groups. According to Andreuci et al, creatinine serum is still used in determining kidney damage although it is less specific and less sensitive. ${ }^{9}$ Statistically, serum Cystatin-C in each treatment group shows slightly significant differences, this shows that copper does not affect levels Cystatin C in serum, although laboratory results show that group 3 antibody concentrations are relatively lower than groups 1 and 2, this is due to the study thats conducted by Prozialek et $\mathrm{al}^{10}$ which shows that has no significant difference in Cystatin-C in cadmium administration.

Cystatin-C levels are not affected by sex, race, body weight, or changes in muscle mass and nutrition. Megalin competes with Cystatin-C in the process of reabsorption in the tubules when albuminuria occurs. Cystatin-C biomarkers can be diagnose acute kidney disorders cause

Table 4 Mean Kidney Histopathologic

\begin{tabular}{|c|c|c|c|}
\hline \multirow{3}{*}{ Treatment Groups } & \multicolumn{3}{|c|}{ Treatments } \\
\hline & 7 Days & 14Days & 21Days \\
\hline & Mean \pm SD & Mean \pm SD & Mean \pm SD \\
\hline Normal control $^{(*)}$ & $0.00 \pm 0.00$ & $0.00 \pm 0.00$ & $0.00 \pm 0.00$ \\
\hline $\begin{array}{l}\text { Pre-TreatmentWhite Tumeric-CuSO4 } \\
\text { Pentahidrat }{ }^{(* *)}\end{array}$ & $0.00 \pm 0.00$ & $0.00 \pm 0.00$ & $0.00 \pm 0.00$ \\
\hline CuSO4 control groups $(* * *)$ & $3.25 \pm 0.50$ & $9.00 \pm 0.00$ & $9.00 \pm 0.00$ \\
\hline
\end{tabular}

Adjectives: Meanserum creatinine \pm standard deviation(SD) $n=5 .(*)$ normal control groups; $(* *)$ the pretreatment group; ${ }^{* * *}$ ) groups induced with $\mathrm{CuSO} 4$ pentahydrate. 

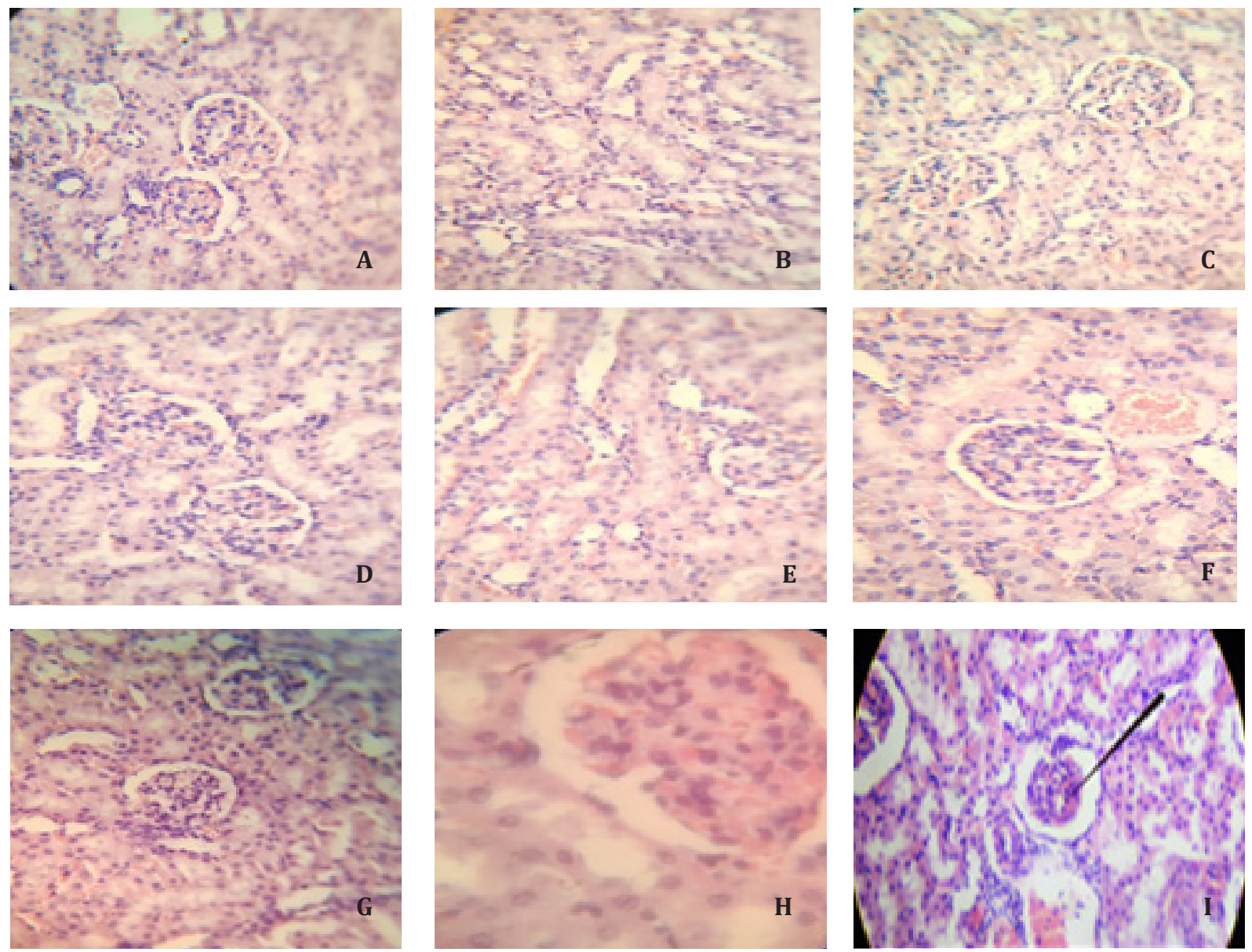

\section{Figure Renal Microscopic Features (H.E magnification of 400x and 1000x) Show Group 1 (Normal Control) with 7 Days Treatment}

(A); 14 days (B); 21 days (C) and Group 2 (white turmeric extract pre-treatment $(45 \mathrm{mg} / 200$ grBB followed by CuSO $40.36 \mathrm{mg} / 200$ grBB) 7 days (D) treatment; 14 days (E); 21 days (F) did not indicate negligence significant renal histology; Group 3 (CuSO4 control $0.36 \mathrm{mg} / 200 \mathrm{grBB}$ ) shows a histologic picture of glomerulus wasting/contracting (arrows) resulting in Bowman's lumen widening and tubular occlusion during treatment for 7 days $(\mathrm{G}) ; 14$ days $(\mathrm{H})$ and 21 days (I)

by nephrotoxic substance earlier than serum creatinine. ${ }^{9}$ From the results of this study Cystatin-C serum concetration in Group 3 is constantly starting to be decreasing on $7^{\text {th }}$ day of treatment than Group 1 and 2. While the serum creatinine levels in Group 3 began to appear increasing on the $14^{\text {th }}$ day of treatment.

Kidney damage due to nephrotoxic substances causes renal vasoconstriction, tubular necrosis and occlusion, molecules transport disorder and vascular congestion due to interstitial inflammation and metabolic disorder. Damages of renal tubules causes an impairement of $\mathrm{Na}+\mathrm{K}+$ ATPase and beta integrin adhesion that disrupted the process of secretion and reabsorption. ${ }^{11}$

In accordance with this study, groups given CuSO 4 pentahydrate for 14 and 21 days have glomerular histological changes where bowman capsules widen and occluded of proximal tubules. In this study, glomerular histological changes in Group 3 is followed with the increasing creatinine serum on day 14 and 21 of treatment. However, the Cystatin-C serum showed low concentrations which started at day $7^{\text {th }}$ without any histologic changes in renal glomerules or tubules.

The administration of white turmeric extract as pre-treatment in Group 2 represent a significant betterment in protein serum concentration compared to Group 1 and Group 3 
FM Wardhani, et al.: Role of Cystatin-C as Serum Biomarkers in Predicting Glomerular Function-Associated with Copper-Induced Acute Kidney Injury

which accord to the research from Al-Eisa et al. ${ }^{12}$ that curcumin which contained in white turmeric has an effect on increasing protein concentration in plasma.On the other hand, the protein level in serum decreases in Group 3 according to research conducted by Khalandar et al. ${ }^{13}$ where the proximal tubule contortus fails to absorb protein molecules. Increased serum protein shows that administration of white turmeric with its antioxidant effect can prevent damage to the tubules from nephrotoxic substances that cause proteinuria.

In conclusion, serum Cystatin- $C$ can be use as alternative diagnose test because of its specific and sensitive characteristic biomarker and can be detected earlier with proximal tubule changes due to exposure to nephrotoxic substances compared to serum creatinine. As a nephroprotective agent, curcumin in turmeric extract has the effect of increasing protein serum due to its antioxidant effect, so in future to increase protein serum, white turmeric can be use as a substitute in treating hypoproteinemia.

In the long term this research needs to be developed further broadly and combined with other disciplines so that people can benefit from the results of this research.

\section{Acknowledgment}

Thank you to the supervisors, Faculty of Medicine, Universitas Prima Indonesia who has guided until the completion of this research. Gratitude also to the Research and Technology Directorate of Higher Education (Ristek Dikti) which has entrusted with providing grant funds to researchers.

\section{References}

1. Wilson L. Toxic metals and human health. Toxic metals in human health and disease. $2^{\text {nd }}$ ed. Mexico: Eck Institute Nutrition Bioenergetics. 2012. p. 1-37.

2. Pratama DA. Efektivitas ampas teh sebagai adsorben alternatif logam $\mathrm{Fe}$ dan $\mathrm{Cu}$ pada air Sungai Mahakam. Journal Integrasi Proses. 2017;6(3):131-8.

3. Trujillo J, Chirino YI, Molina-Jijón E, AndéricaRomero AC, Tapia E, Pedraza-Chaverrí J. Renoprotective effect of the antioxidant curcumin: Recent findings. Redox Biology. 2013;1(1):448-56.

4. Adiyanti SS, Loho T. Acute kidney injury (AKI) biomarker. Acta Medica Indonesiana. 2012;44(3):246-55.

5. Dodiya H, Jain M, Goswami S. Study of urinary biomarkers for nephrotoxicity in wistar rats. J Pharmacol Toxicol. 2011;6(6):571-9.

6. Setiawan D, Harun H, Azmi S, Priyono D. Biomarker acute kidney injury (aki) pada sepsis. Jurnal Kesehatan Andalas. 2018;7(Supplement 2):113-8.

7. Hashish EA, Elgaml SA. Hepatoprotective and nephroprotective effect of curcumin against copper toxicity in rats. Indian J Clin Biochemis. 2016;31(3):270-7.

8. Banks RE. Guinea pig. Exotic small mammal care and husbandry. Iowa, Ames (IA): WileyBlackwell; 2010. p. 85-92.

9. Andreucci M, Faga T, Pisani A, Perticone $\mathrm{M}$, Michael A. The ischemic/nephrotoxic acute kidney injury and the use of renal biomarkers in clinical practice. Eur J Intern Med. 2017;39:1-8.

10. Prozialeck WC, VanDreel A, Ackerman CD, Stock I, Papaeliou A, Yasmine C, et al. Evaluation of cystatin $\mathrm{C}$ as an early biomarker of cadmium nephrotoxicity in the rat. BioMetals. 2016;29(1):131-46.

11. Adiyanti SS, Loho T. Acute kidney injury (AKI) biomarker. Acta Med Indones. 2012; 44(3):246-55.

12. Khouja H. Turmeric (Curcuma Longa) protection against the liver toxicity caused by aluminum chloride ( $\mathrm{AlCl} 3$ ) in adult male rats. Int J Pharm Res Allied Sci. 2017;6(2): 110-27.

13. Khalandar SD, Adithya TN, Basha SJ, Koshma M, Subbareddy UV, Reddy V. A current review on curcuma longa linn. Plant. Int J Pharm Chem Biol Sci. 2018;8(1):68-73. 